\title{
Harvesting System Suitability as Decision Support in Selection Cutting Forest Management in Northwest Bosnia and Herzegovina
}

\author{
Dane Marčeta, Vladimir Petković, Darko Ljubojević, Igor Potočnik
}

\begin{abstract}
Planning of forest harvesting operations is one of the key elements of successful forest management. The integration of modern tools and traditional forestry procedures is something that must be done in contemporary forestry. This research investigated the use of multicriteria decision support (AHP) and GIS in choosing the optimal harvesting system for predominantly selection cutting forest management on the example of two Forest Management Units (FMU). Results showed that AHP could be easily integrated into GIS using the extAHP tool and its results could be of help, along with other input data, in choosing the optimal harvesting system. Spatial analysis of raster data in GIS gives a comprehensive insight into the stand and terrain characteristics and shows the relative share of the area proposed for each system. In FMU »Kozara-Mlječanica", the harvesting system chainsaw-skidder had the highest relative share with $44 \%$ of the area, meaning that it is almost the only harvesting system in current use, followed by chainsaw-forwarder (36\%), chainsaw-cable yarder (19\%), and chainsawadapted agriculture tractor (AAT) (1\%). The system harvester-forwarder was not used at all, which is understandable considering that FMU »Kozara-Mlječanica " has a higher average slope and higher diameter of trees to be cut than FMU »Prosara", where harvester-forwarder system accounts for a significant $36 \%$ of the area. The dominant system in FMU »Prosara" was chainsaw-forwarder ( $42 \%)$, followed by chainsaw-cable yarder (17\%), chainsaw-skidder $(4 \%)$ and chainsaw-AAT (1\%). It should be noted that the presence of chainsaw-skidder system is insignificant. It is replaced by the system chainsaw-forwarder. Traditional harvesting system chainsaw-skidder, which prevails in Bosnia and Herzegovina, should be upgraded with the new technologies and methods. Using tools like multicriteria decision support and GIS could be of great help in that process.
\end{abstract}

Keywords: harvesting systems, criteria, AHP, GIS, raster analysis

\section{Introduction}

A very important factor that influences the planning quality of forest harvesting operations is the availability of quality information about stand and terrain characteristics, management goals, accessible technology and forest infrastructure. Forestry practitioners use various sources to gather necessary data for operational planning. They take some information from forest management plans and they collect some themselves during the development of operational plans. In order to efficiently handle all these data and make a good decision, they use GIS, GPS, handheld computers, multicriteria decision support and various other tools. Some researchers developed specific applications for using multicriteria decision support in forestry, such as $\mathrm{MPC}^{\odot}$ software (Perez-Rodriguez and Rojo-Alboreca 2012). Combination of GIS and analytic hierarchy process (AHP) could improve making and prioritising operational decisions in forestry (Pellegrini and Grigolato 2013, Babapour et al. 2014)

For efficient planning of forest operations, it is of crucial importance to have technical-technological 
terrain classification of the forest area. It assumes that there is a terrain classification based on various factors, like climate, relief, soil, stand characteristics, harvesting methods, and others. In order to be efficient, harvesting operations should be based on a properly planned forest transportation network, suitable equipment and machines, and well-trained workers (Marčeta 2015).

Strategic and tactical decisions in forest harvesting have long-term consequences on the sustainability of forest management. Decisions about actions are often based on the experience or intuition and further outcome of such actions is usually uncertain (Kühmaier and Stampfer 2010). Production of timber is usually the most important aim of forest management. Choices in selecting the primary aim are mostly based on experience and intuition and often do not consider a long-term and sustainable strategy of resource management (Lüthy1998).

Forest harvesting in Bosnia and Herzegovina $(\mathrm{B} \& \mathrm{H})$ still relies on the use of chainsaw and skidder, and assortment harvesting method. To some extent, animals are used for skidding and extraction of fuelwood. Other technologies, like harvesters, processors, cable-yarders and forwarders are not used at all, or their use is negligible. Assortment method is the most common harvesting method, half-tree length and full tree length are practised rarely, while the whole tree and chipping methods are not practised at all (Marčeta 2015). Although skidders are not suitable for skidding of short wood in assortment method, they are widely used. The consequence of such approach is that they always work below their optimal capacity (Marčeta et al. 2014). The working costs incurred and introduction of new technologies consequently create a constant need for a review of suitability of the existing harvesting systems. Various decision support tools are used to measure the success of changes, especially for tactical and strategical goals. Changing of the forest road network or introducing new harvesting systems usually have a serious impact on the costs, ecological and social issues, and productivity. Well-grounded analysis of harvesting systems should take stand and terrain data, as well as, ecological, economic and social impacts into account (Sheppard et al. 2005, Wolfslehner et al. 2008, Kangas et al. 2008, Đuka et al. 2018). In general, economic efficiency has usually been the main criterion for selecting harvesting systems, especially in developing countries like $\mathrm{B} \& \mathrm{H}$, where sustainable forestry has not always been the first concern.

Decision problem in forestry operations involves many criteria and bears many compromises. It is not an easy task to find a suitable solution without using various technical and mathematical tools. For that reason, a multi-criterion, computer-aided decision support is a suitable approach (Lexer et al. 2005, Kangas and Kangas 2005). Harvesting operations are carried out at a wide-spread area, in diversified conditions, and the best way to get to know them is to use some of the GIS software. Forestry was one of the first pioneers in putting GIS applications and methods of remote sensing into practice. These technologies have become a standard tool for acquiring, updating, analysing, and presenting spatial data (Synek and Klimánek 2014). GIS for assessing soil trafficability was initially used for military off-road planning, after which these applications were introduced to forest and agricultural applications (Lubello 2008).

Planning of forest operations, such as timber harvesting, is a very complex task, especially in mountain regions (Ezzati et al. 2016, Stückelberger et al. 2007, Đuka et al. 2017). The difficulty in planning arises from diverse topographic conditions, while the challenge is to find a solution for multiple, sometimes conflicting aims. To do so, many sources of information must be incorporated into the decision-making process (Gond et al. 2011, Troncoso et al. 2015). Over the past few decades, harvesting planning has been under intense analysis because the public is increasingly concerned about visual impacts and unplanned environmental consequences of timber harvesting in steep, mountainous areas that are particularly prone to soil erosion or slope failure (Pentek et al. 2008, Jaafari et al. 2015).

The complexity of decision making in forestry is associated with dimensions and categories, which range from: long term (strategic) to short term (operational) on a temporal scale, stand level to national level in a spatial scale, and individual to group decision making (Blagojević et al. 2019). Another issue is that various stakeholders participating in the decisionmaking process can have different or opposite priorities, objectives, and goals, which may lead to conflicts (Diaz-Balteiro and Romero 2008).Thus, within the context of existing best management practices (BMPs), planning needs to address the strategies to mitigate the expected adverse impacts of management activities in fragile mountain ecosystems and legitimise the planning process itself by involving diverse stakeholders and the public in the decision-making process (Ezzati et al. 2016).

Although great progress has been made over the past decades to analyse and design better harvest operations in steep terrain, the primary focus of these efforts has been on increasing economic efficiency as the overarching management goals (Adams et al. 2003, Pentek et al. 2008, Kühmaier and Stampfer 2010). This narrow-minded focus has been increasingly criticised, 
because the neglecting of other objectives may result in unplanned adverse side-effects that may ultimately override any economic advantage (Pentek et al. 2008, Wolfslehner and Vacik 2008).

A favourable approach to achieve this multifunctionality is through a spatial diversification of the landscape, whereby similar management units with identical objectives are grouped into management units (Boyland et al. 2004). This approach could provide an efficient planning model that can achieve a high level of fulfilment, particularly when taking into account that the diversification of objectives is a management concern in many mountain areas where limited feasible land units are available for conducting timber harvest (Adams et al. 2003, Epstein et al. 2006). The advantage of this approach is that the planning process becomes understandable and can be easily incorporated into traditional harvest scheduling models (Richards and Gunn 2000).Technical challenges of mountain forest harvest planning are not only limited to the identification of feasible harvest zones, but they also deal with the assignment of efficient harvesting systems (Kühmaier and Stampfer 2010, Ghajar et al. 2010) and the placement of landing sites (Ezzati et al. 2015, Contreras et al. 2016).

While the expertise of forest engineers is often sufficient for making functional small-scale spatial planning decisions for selecting feasible management alternatives, they often fail to make the best decisions when multiple and competing decision criteria are involved in larger scale planning efforts (Ezzati et al. 2016, Kazana et al. 2003, Stückelberger et al. 2006, Chung et al. 2008). This failure can lead to excessive site damage and adverse economic consequences if planners are not sufficiently familiar with the conditions of the management area. Many of the above studies have described methods primarily focused on terrain classification to create appropriate spatial area for harvesting, which relied on mathematical modelling or used single-criterion analysis. However, a more wide-ranging planning method should be introduced when integrating terrain classification with environment and stand factors.

Multicriteria decision analysis (MCDA) is a powerful method that includes a set of tools for the control of decision-making process. MCDA is structuring the decision-making procedure in a way that cannot be achieved with an ordinary unstructured decisionmaking process (Mendoza and Martins 2006).The analytic hierarchy process (AHP), originally developed by Saaty $(1977,2008)$, is a widely used MCDA method and perhaps the most popular in many fields, including natural resource management (Kangas and
Kangas 2005). AHP has numerous advantages from the perspectives of multiple-use and participatory planning. Using AHP, objective information, expert knowledge, and subjective preferences can be considered together (Kangas and Kangas 2005). Also, qualitative criteria can be included in the evaluation of alternative plans. AHP is based on a theory of ratio-scale estimation (Saaty 1977), and by using it, pair-wise comparisons of qualitatively expressed measures can be transferred into a ratio scale. The AHP has the potential for prioritising and ranking criteria for forest road planning, where a set of data must rely in part on professional judgement. AHP provides decision makers with a structured means of incorporating both scientific data and professional judgements (Norizah and MohdHasmadi 2012). AHP was also used to define the benefit of maintenance and upgrade projects for lowvolume forest roads (Coulter et al. 2006). Gerasimov et al. (2013) examined A'WOT analysis as a tool for development programmes in wood procurement in Russia.

The harvesting method is determined by the form in which timber is transported to the forest landing, depending on the level of processing at the stump. Harvesting system refers to technologies, i.e. machines and equipment used for harvesting of some forest area (Krpan and Poršinsky 2004, Pentek et al. 2008). Heinimann $(2000,2004)$ selected four basic concepts of harvesting systems. Timber extraction could be performed with special forest vehicles (skidders and forwarders), cable yarders or helicopters. System complexity increases with the effort to ensure off-road locomotion. Skidders and forwarders may move offroad over natural terrain (skid trail) or, if the terrain conditions become too sensitive, over the built skid roads. In difficult terrain conditions, cable yarders enable the transport of partially or fully suspended loads over large distances (Pentek at al. 2008). Natural forests with selection forest management are especially demanding for planning and execution of operations.

Mechanisation of felling and processing with harvesters was first performed on gentle terrain and was gradually transferred to slopes. Availability of new technology (self-levelling wheeled platforms, legged platforms, platforms with four independent trapezoidal tracks) will make it possible to apply harvesters even on slopes up to 70\% (Stampfer 1999, Stampfer and Steinmüller 2001). Diameter breast height DBH is still the main limiting factor for using harvesters (Pentek et al. 2008). Using harvesters in selection cutting forests in hilly and mountain area of $\mathrm{B} \& \mathrm{H}$ is still a debatable topic, while forwarders are less questionable but still very rarely used. Harvester operator can 
Table 1 Investigated area stand characteristics (PFE ॥Šume Republike Srpske» 2018)

\begin{tabular}{|c|c|c|c|c|c|c|c|c|}
\hline \multirow{3}{*}{ Forest classification } & \multicolumn{3}{|c|}{ FMU »Prosara» } & \multicolumn{3}{|c|}{ FMU „Kozara-Mlječanica» } & \multirow{2}{*}{\multicolumn{2}{|c|}{ Total }} \\
\hline & \multicolumn{2}{|c|}{ Area } & \multirow{2}{*}{$\frac{\text { Growing stock }}{\mathrm{m}^{3} / \mathrm{ha}}$} & \multicolumn{2}{|c|}{ Area } & \multirow{2}{*}{$\frac{\text { Growing stock }}{\mathrm{m}^{3} / \mathrm{ha}}$} & & \\
\hline & ha & $\%$ & & ha & $\%$ & & ha & $\%$ \\
\hline High forests with natural regeneration & 2705 & 83.7 & 344 & 8233 & 92.6 & 414 & 10,938 & 90.2 \\
\hline Forest plantations & 183 & 5.7 & 220 & 291 & 3.3 & 337 & 474 & 3.9 \\
\hline Coppice forests & 374 & 11.6 & 181 & 246 & 2.8 & 176 & 621 & 5.1 \\
\hline Other forest area & 29 & 0.9 & - & 121 & 1.4 & - & 151 & 1.2 \\
\hline Total & 3232 & 100.0 & - & 8891 & 100.0 & - & 12,124 & 100.0 \\
\hline
\end{tabular}

strictly control the felling direction, and thus reduce damages to the remaining stand and soil. Trees of large dimensions or with a complex position of branches that hinder the harvester felling head could be felled with the chainsaw and processed by harvester. Such work organisation and restriction of clear cutting on very small areas is not a limiting factor for excluding the use of harvesters but has a strong influence on productivity and efficiency, as well as on the level of damages.

The aim of this research is to investigate the suitability of integration of GIS software and multicriteria decision support tool in choosing the optimal forest harvesting system for two Forest Management Units (FMU) in dominantly natural forests, with selection cutting management system, in the mountain and hilly-mountain relief.

\section{Material and Methods}

\subsection{Research Object}

The investigation was done in two Forest Management Units (FMU), "Prosara " and "KozaraMlječanica «, which are part of the Forest Management Administration (FMA)»Prijedor « (Fig. 1). The relief of this area is mostly mountainous and hilly. The total area of investigated FMUs is 12,124 ha, and over $90 \%$ of the area is predominantly covered by high forests with natural regeneration (Table 1). Beech and sessile oak are the main tree species of high forests in both FMU, but in »Kozara-Mječanica « silver fir is present in a significant amount. The share of other tree species is insignificant.

Both FMUs consist of compartments, which have been harvested in 10-year cycles, using harvesting system chainsaw-skidder and assortment harvesting method. The forest transport infrastructure is based on the primary and secondary network, where the primary network consists of forest roads with the openness of $12.79 \mathrm{~m} / \mathrm{ha}$ in FMU »Prosara « and $9.16 \mathrm{~m} /$ ha in FMU »Kozara-Mlječanica«. The secondary network consists of skid roads and skid trails, planned at the level of the compartment, where openness usually varies from 100 to $200 \mathrm{~m} / \mathrm{ha}$. Cutting intensity for such kind of forest management system ranges within borders from 15 to $20 \%$ of the total growing stock for high

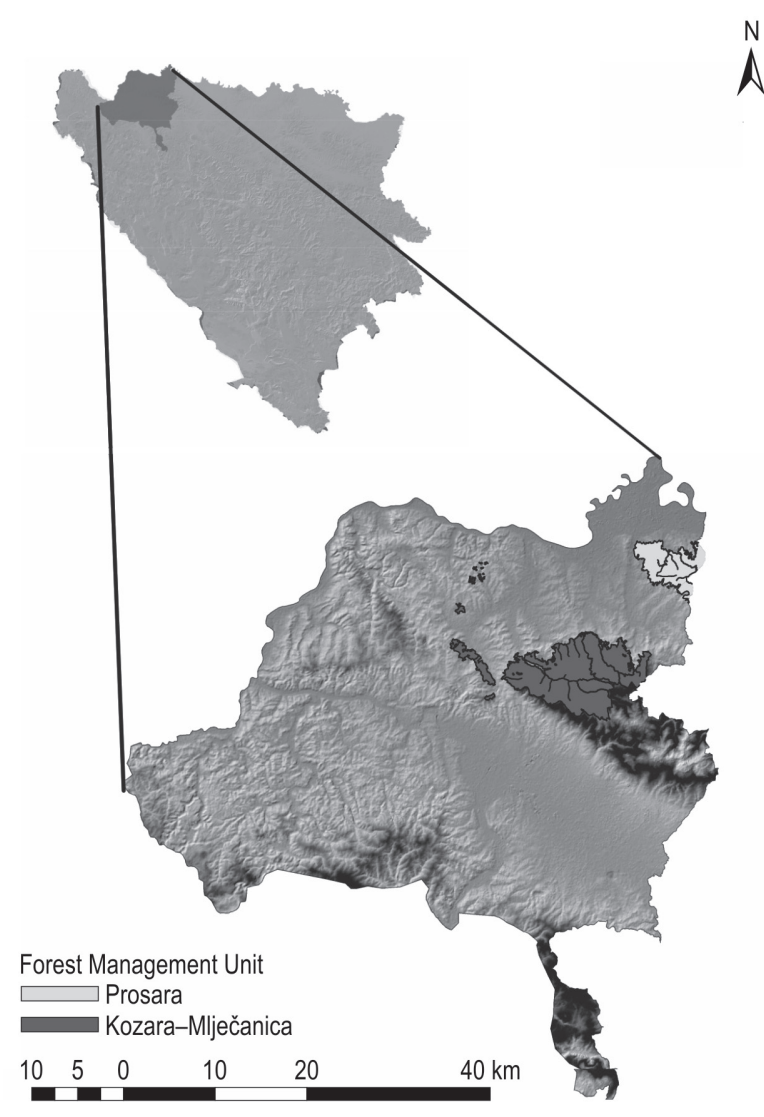

Fig. 1 FMA »Prijedor» 
forests with natural regeneration, which is carried out according to forest management plan by PFE »Šume Republike Srpske« Ltd.

\subsection{Method}

\subsubsection{Selection of Influencing Factors}

In order to collect reliable inputs for AHP, a questionnaire was developed and distributed to the forestry scholars and practitioners, whose expertise is close to forest technique and technologies. Respondents were chosen based on the personal judgment of researchers (Malhotra 2007). The questionnaire is prepared in such a way that answers are classified in accordance with Saaty scale (Saaty 1977). The most important criteria that have an impact on harvesting operations were identified and graded according to their importance. Criteria are divided into three groups: relief, stand and technological (Table 2). Five harvesting systems were chosen for analysis; these systems are currently in use or have potential to be introduced in practice. Limiting factors for harvesting systems are presented in Table 2.

Values of slope, above or below limiting, are not totally excluded, i.e. they are assigned with null, so they are included in calculation with less probability of choice. Although it is related to terrain slope, rather than yarding trail slope, values of the slope are subtracted from value 1 in all systems except chainsaw- cable yarder. With the exception of the chainsaw-cable yarder system, all considered harvesting systems prefer lower values of terrain slope. In the case of the chainsaw-cable yarder system, higher slope values are more preferable. Soil depth is categorised into three groups according to available data from forest management plan (1 - shallow, high bearing, 2 - medium deep, 3 - very deep, moist, low bearing) (PFE »Šume Republike Srpske « 2018). Each harvesting system is assigned to a suitable category. The forest management system is evaluated over cutting intensity. Higher intensity is preferable in all harvesting systems. Allowable cutting volume is the criterion where higher values are preferable in all harvesting systems. DBH is included in the analysis in the way that values, which are out of limit for a specific harvesting system, are coded with null., The average yarding distance is coded in the same way. Harvesting method is diversified according to average piece size, based on forest inventory data and technical standards (Šipad Irc Oour Silva 1989). It is adopted that average piece size for assortment method is $0.5 \mathrm{~m}^{3}$, for half-tree length $1.0 \mathrm{~m}^{3}$ and $1.5 \mathrm{~m}^{3}$ for tree length. Most of the data used for this research were gathered during forest inventory, which is carried out by the method of setting up of sampling plots in the grid $100 \times 100 \mathrm{~m}$. These plots consist of concentric circles with different radius and it is regularly done in ten-year cycles. For the purpose of this investigation, a database was created with coordinates of each concentric circle, which

Table 2 Limiting values for harvesting systems (Sources: Šipad Irc Oour Silva 1989, Pentek et al. 2008, Heinimann 2000, Heinimann 2004, Laengin et al. 2010)

\begin{tabular}{|c|c|c|c|c|c|c|c|}
\hline \multirow{4}{*}{ Harvesting system } & \multicolumn{7}{|c|}{ Criterion } \\
\hline & \multicolumn{2}{|c|}{ Relief } & \multicolumn{3}{|c|}{ Stand } & \multicolumn{2}{|c|}{ Relief } \\
\hline & \multicolumn{7}{|c|}{ Subcriterion } \\
\hline & $\begin{array}{l}\text { Slope } \\
\%\end{array}$ & $\begin{array}{l}\text { Soil } \\
\text { depth } \\
\text { group }\end{array}$ & $\begin{array}{c}\text { Forest management } \\
\text { system }\end{array}$ & $\begin{array}{c}\text { Allowable } \\
\text { cut } \\
\text { volume }\end{array}$ & $\begin{array}{l}\mathrm{DBH} \\
\mathrm{cm}\end{array}$ & $\begin{array}{c}\text { Average yarding } \\
\text { distance } \\
\text { m }\end{array}$ & $\begin{array}{l}\text { Harvesting } \\
\text { method }\end{array}$ \\
\hline $\begin{array}{l}\text { Chainsaw - Adapted } \\
\text { agriculture tractor (ATT) }\end{array}$ & $<60$ & $1-2$ & All & All & $<45$ & $<250$ & assortment \\
\hline Chainsaw - Skidder & $<60$ & $1-2$ & All & All & All & $<500$ & $\begin{array}{l}\text { assortment } \\
\text { half-tree length } \\
\text { tree length }\end{array}$ \\
\hline Chainsaw - Forwarder & $<60$ & $1-2-3$ & All & All & All & $<1000$ & assortment \\
\hline Harvester - Forwarder & $<40$ & $1-2-3$ & All & All & $<40$ & $<1000$ & assortment \\
\hline Chainsaw - Cable Yarder & $>60$ & $1-2-3$ & All & All & All & $<40$ & $\begin{array}{l}\text { assortment } \\
\text { half-tree length } \\
\text { tree length }\end{array}$ \\
\hline
\end{tabular}


are overlapped with maps of stands and compartments. In this way, necessary data for each compartment and stand can be extracted.

\subsubsection{Multicriteria Evaluation}

The stand is the basic unit used for the evaluation of harvesting system suitability. The obtained values of criteria are assigned to each stand. All values are standardised in order to be comparable between criteria. Original values are standardised using eq. 1.

$$
X_{\mathrm{i}}=\frac{\left(R_{\mathrm{i}}-R_{\min }\right)}{R_{\max }-R_{\min }} \times X_{\max }
$$

Where:

$X_{i} \quad$ standardised value

$R_{\mathrm{i}} \quad$ basic value

$R_{\text {min }} \quad$ lower value of basic scale

$R_{\max } \quad$ upper value of basic scale

$X_{\max } \quad$ upper average value of standardized scale.
Standardised values are rasterised so that the multicriteria decision model could be applied for the evaluation of suitability of each stand for the analysed harvesting systems. In this way, rasters of criteria values are defined for each stand. Determination of suitability is performed based on relative weights of the criteria, calculated by partial-pairwise comparison with AHP method, based on evaluations obtained in questionnaires. The application of the AHP method is integrated into ArcGIS software through software extension extAHP, developed by Oswald Marinoni (Marinioni 2004). In this extension, rasters of criteria are entered, and weights of the coefficients are assigned in the table of partial-pairwise comparison. Based on the raster of criteria and weights, the suitability map for each stand is obtained. Finally, the system selection is made at the stand level. After the multicriteria analysis with AHP is conducted, the most preferred system for each stand is obtained with ArcGIS
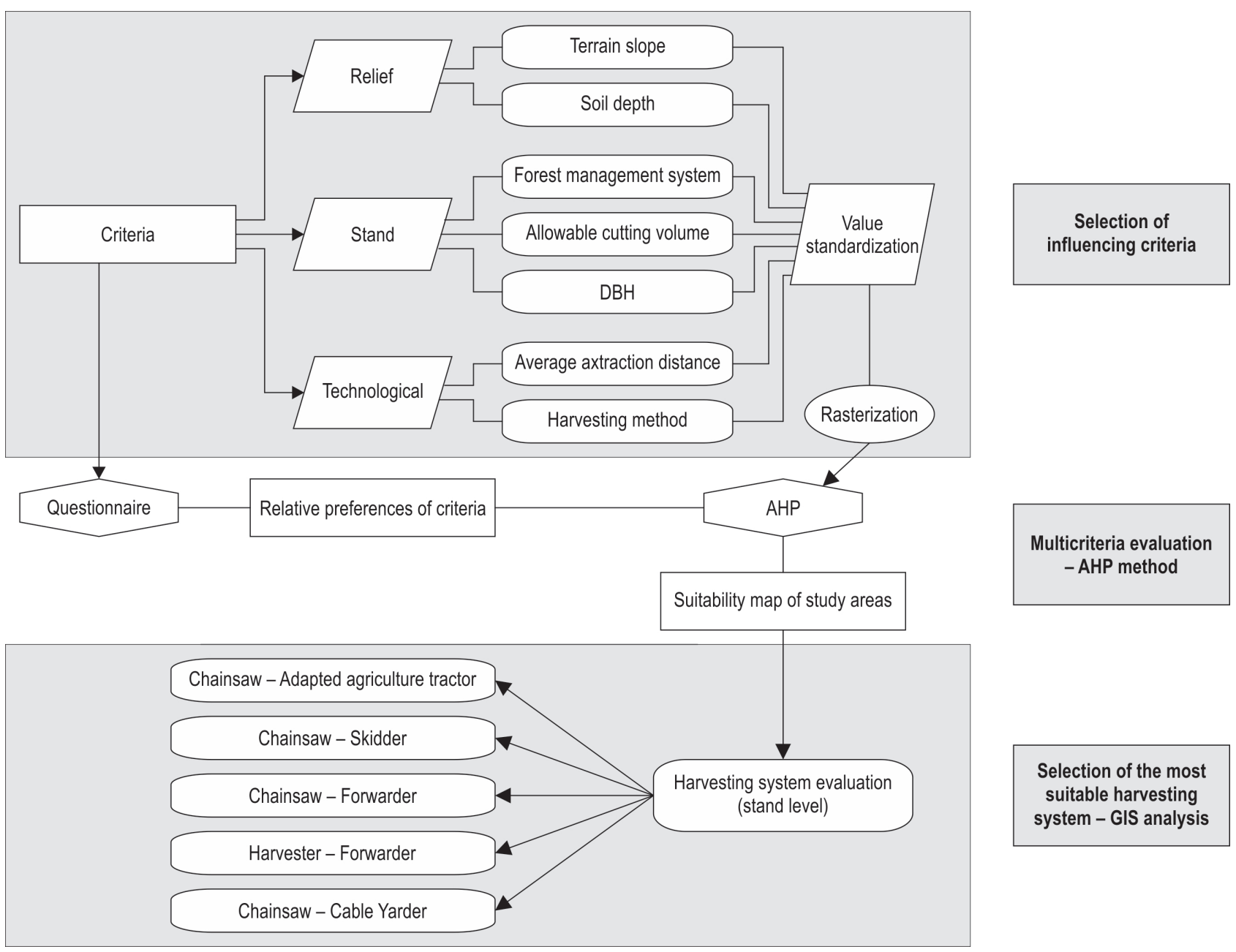

Fig. 2 Research flowchart

Selection of the most suitable harvesting system - GIS analysis 
Table 3 Average values of criteria evaluations

\begin{tabular}{|c|c|c|c|c|c|c|c|}
\hline \multirow{4}{*}{ Harvesting system } & \multicolumn{7}{|c|}{ Criterion } \\
\hline & \multicolumn{2}{|r|}{ Relief } & \multicolumn{3}{|c|}{ Stand } & \multicolumn{2}{|c|}{ Relief } \\
\hline & \multicolumn{7}{|c|}{ Subcriterion } \\
\hline & $\begin{array}{l}\text { Slope } \\
\%\end{array}$ & Soil depth group & $\begin{array}{c}\text { Forest management } \\
\text { system }\end{array}$ & $\begin{array}{l}\text { Allowable cut } \\
\text { volume }\end{array}$ & $\begin{array}{c}\mathrm{DBH} \\
\mathrm{cm}\end{array}$ & $\begin{array}{c}\text { Average yarding } \\
\text { distance } \\
\text { m }\end{array}$ & Harvesting method \\
\hline Chainsaw - AAT & 2.88 & 2.07 & 1.80 & 1.60 & 2.07 & 2.53 & 2.40 \\
\hline Chainsaw - Skidder & 2.38 & 2.19 & 1.88 & 2.00 & 1.75 & 2.50 & 2.19 \\
\hline Chainsaw - Forwarder & 2.56 & 2.44 & 2.31 & 2.13 & 2.00 & 2.06 & 2.63 \\
\hline Harvester - Forwarder & 2.50 & 2.50 & 2.63 & 2.50 & 2.25 & 1.88 & 2.19 \\
\hline Chainsaw - Cable Yarder & 1.94 & 1.19 & 2.50 & 2.50 & 1.88 & 1.94 & 2.13 \\
\hline
\end{tabular}

Spatial analyst tool. Cell statistic tool is used, and the harvesting system with a maximum number of points obtained in the previous stage represents the most preferred system for each specific stand. Research flow is presented in Fig. 2.

\section{Results and Discussion}

After the questionnaire was conducted, during which 16 of 20 questioned respondents gave their opinions and evaluated the importance of criteria, an-

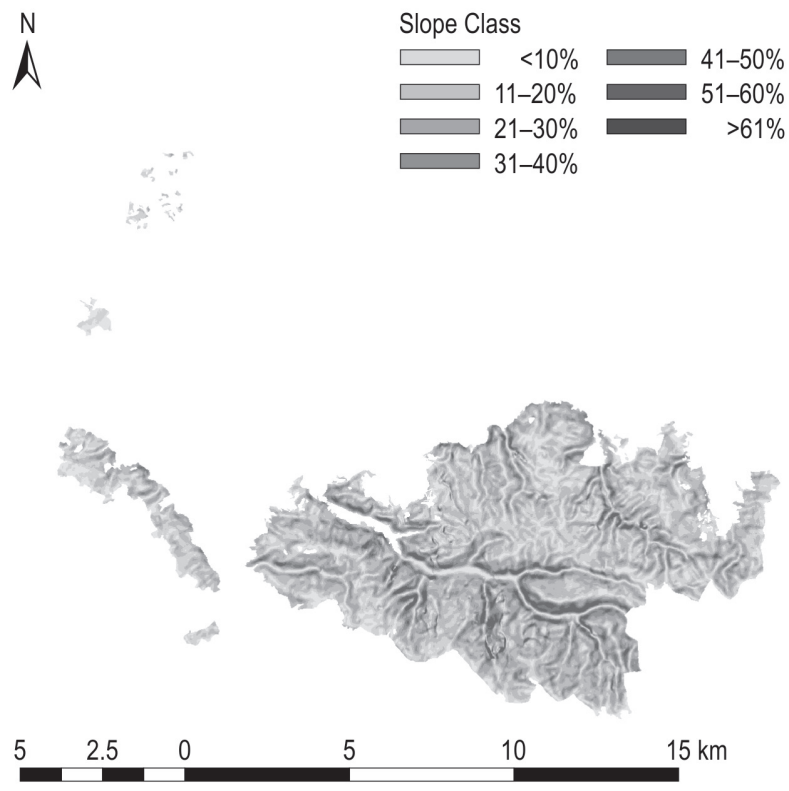

Fig. 3 Slope distribution - FMU »Kozara-Mlječanica» swers were entered in ArcGIS with the extAHP tool. The average values of their answers are presented in Table 3.

Slope distribution of both FMUs (Fig. 3 and 4) shows that in FMU »Prosara « $81.2 \%$ of the area has a slope up to $40 \%$, which is slightly less than in FMU »Kozara-Mlječanica « where $84.3 \%$ of the area is below $40 \%$. The share of very high slope area $(>60 \%)$ is higher in FMU »Kozara-Mlječanica« $(2.4 \%)$ than in FMU »Prosara « $(1.1 \%)$, which is important for the implementation of chainsaw-cable yarder harvesting system.

\section{$\stackrel{N}{\Lambda}$}

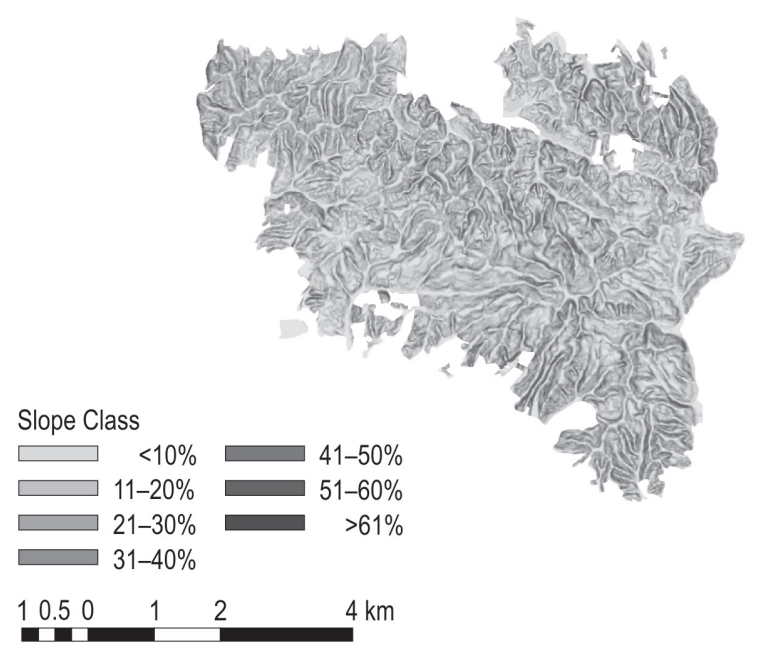

Fig. 4 Slope distribution - FMU »Prosara» 


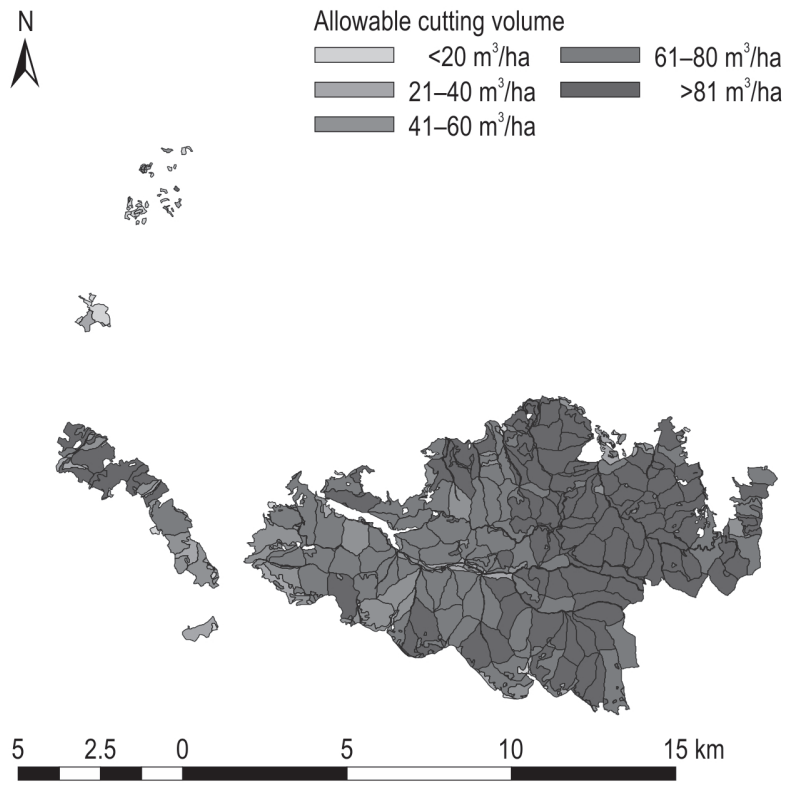

Fig. 5 Allowable cut - FMU »Kozara-Mlječanica»

$N$

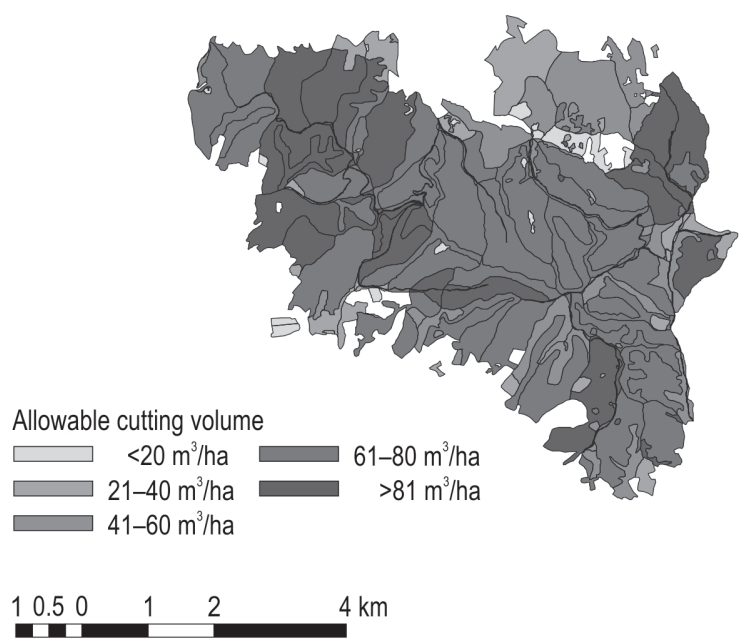

Fig. 6 Allowable cut - FMU »Prosara»

The allowable cutting volume is a very significant factor that has an impact on the harvesting system because it is connected to machine productivity and costs. The allowable cutting volume is over $60 \mathrm{~m}^{3} / \mathrm{ha}$ on over $80 \%$ of the area in both FMUs, while the allowable cutting volume is over $80 \mathrm{~m}^{3} /$ ha on $51.1 \%$ of the area of FMU »Kozara-Mlječanica« (Fig. 5 and 6).

Maps of cutting intensity and soil depth (Fig. 7-10) show than FMU »Prosara« has slightly higher cutting

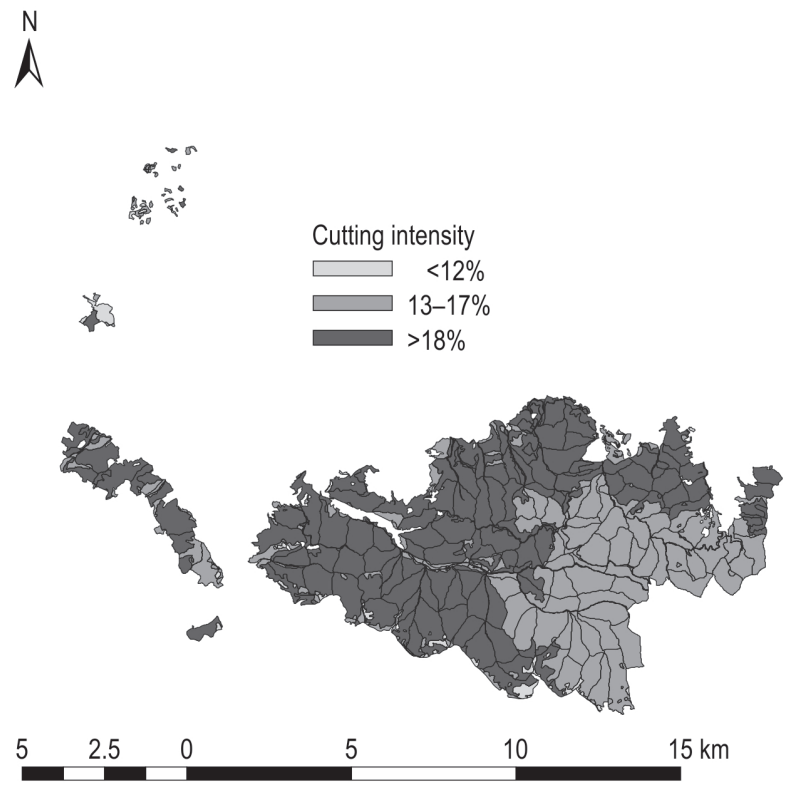

Fig. 7 Cutting intensity - FMU »Kozara-Mlječanica»<smiles>NC1=CC1</smiles>

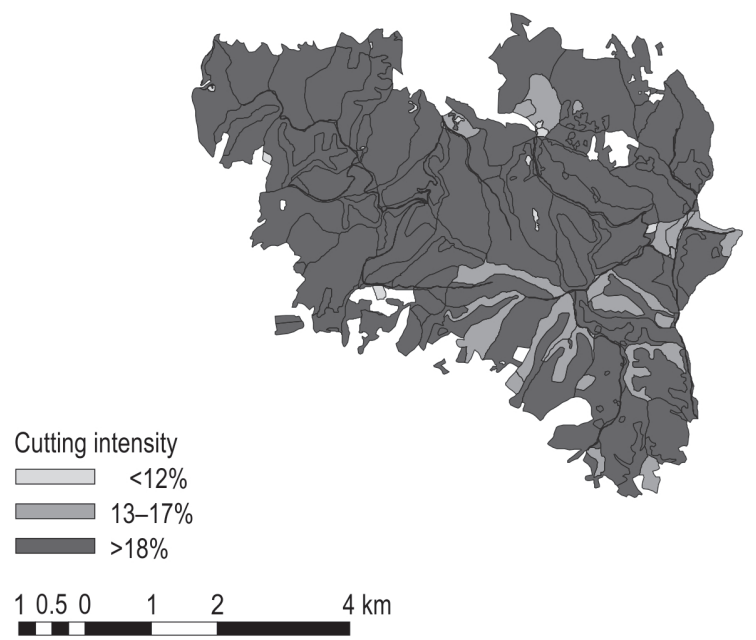

Fig. 8 Cutting intensity - FMU »Prosara»

density and relative share of very deep soils than FMU »Kozara-Mlječanica «. Spatial distribution of the average DBH of the cutting tree (Fig. 11 and 12) shows that the average $\mathrm{DHB}$ of the cutting tree is above $40 \mathrm{~cm}$ on $67.4 \%$ of the area of FMU »Prosara «, while in the area of FMU »Kozara-Mlječanica «, the cutting DBH is over $40 \mathrm{~cm}$ on as much as $83.6 \%$ of the area. These facts are very important in decision-making processes, considering that $\mathrm{DBH}$ of $40 \mathrm{~cm}$ is often a limiting 


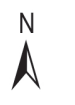

Soil depth

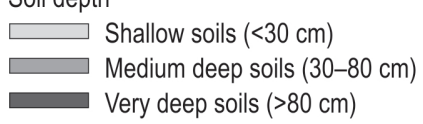

$\underset{\substack{\infty \\ 0 \rightarrow \infty}}{\infty \rightarrow \infty}$

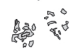

रु

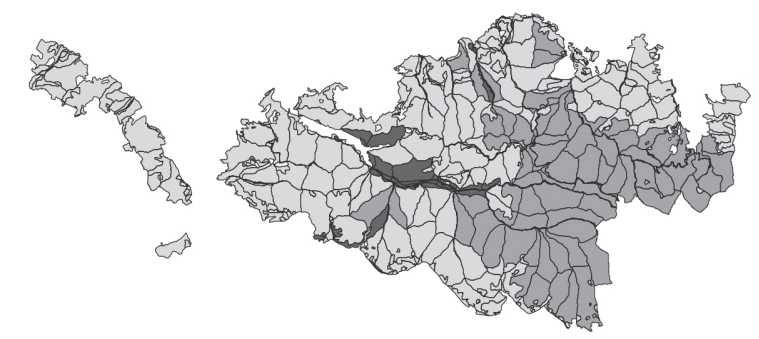

5

2.5

0

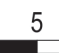

10

Fig. 9 Soil depth - FMU „Kozara-Mlječanica»

$\bigwedge^{N}$

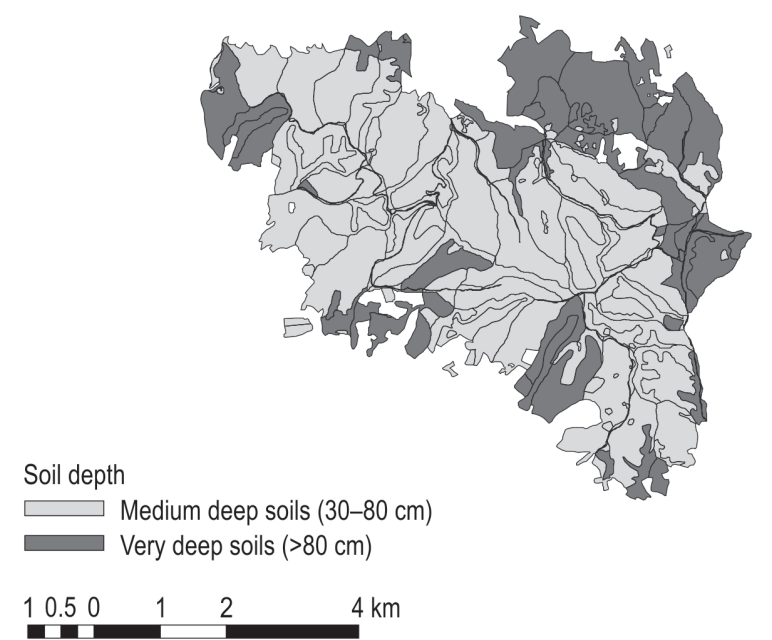

Fig. 10 Soil depth - FMU „Prosara»

factor for the use of harvesters (Pentek et al. 2008), while some authors stated that the limiting DBH for broadleaves is $50 \mathrm{~cm}$ (Kühmaier and Stampfer 2010).

Both FMUs have very diversified secondary accessibility (Fig. 13 and 14), where the average yarding distance varies from less than $250 \mathrm{~m}$ to over $1000 \mathrm{~m}$. High yarding distance is unfavourable for the costs of primary transport, and often a crucial limiting factor

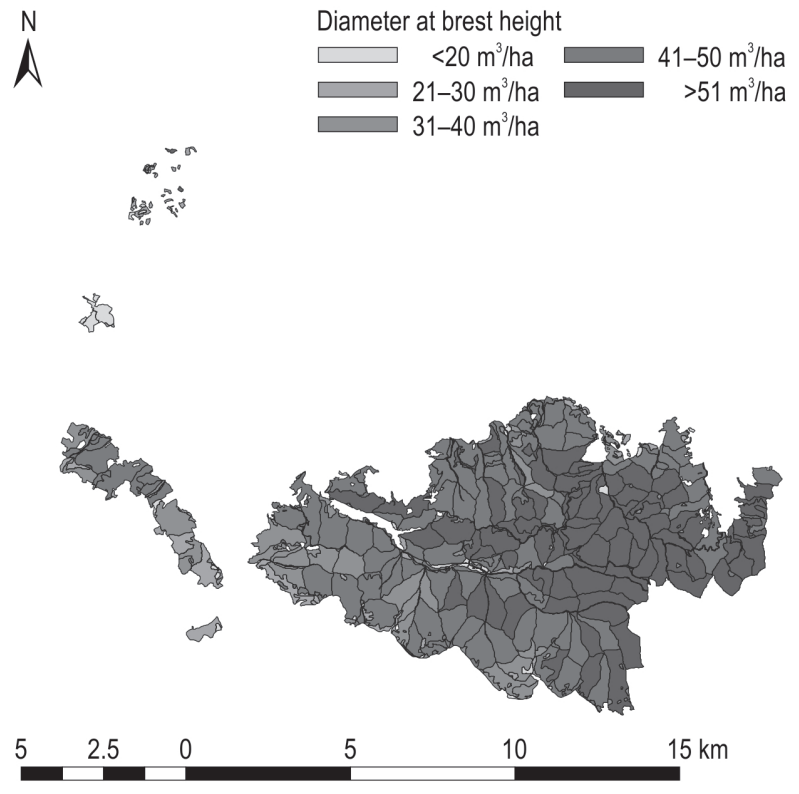

Fig. 11 DBH cut distribution - FMU »Kozara-Mlječanica»

$\AA^{N}$

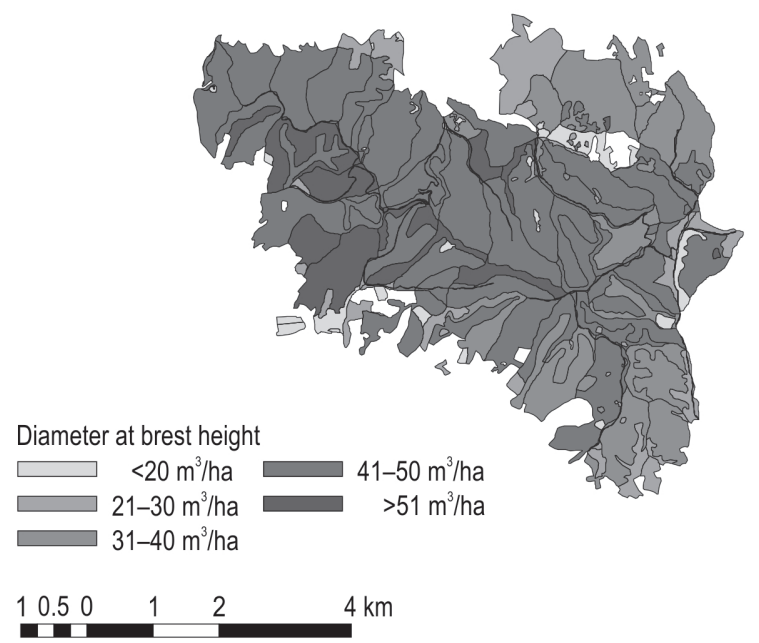

Fig. 12 DBH cut distribution - FMU »Prosara»

for using specific machinery. Operational planners are often torn between the need to build new transport network and reduce the investment costs. When considering the harvesting methods, Fig. 15 and 16 show that all three methods are equally represented in FMU "Kozara-Mlječanica", while the tree length method is only slightly represented in FMU »Prosara«.

Harvesting suitability maps (Fig. 17 and 18) were created based on the above described methodology, 
D. Marčeta et al. Harvesting System Suitability as Decision Support in Selection Cutting Forest Management ... (251-265)

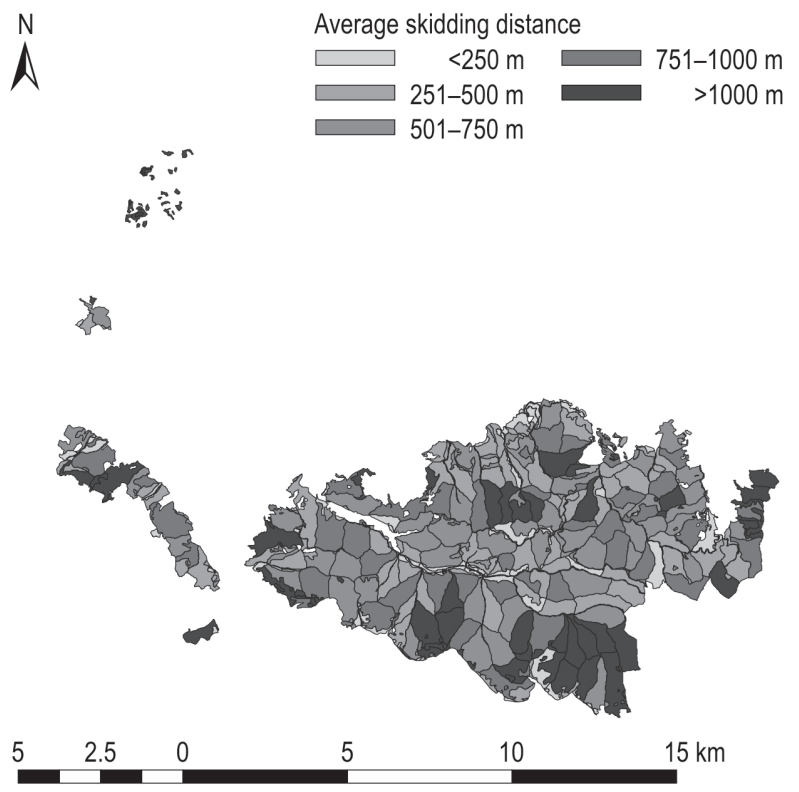

Fig. 13 Yarding distance - FMU »Kozara-Mlječanica»

$\stackrel{N}{N}$

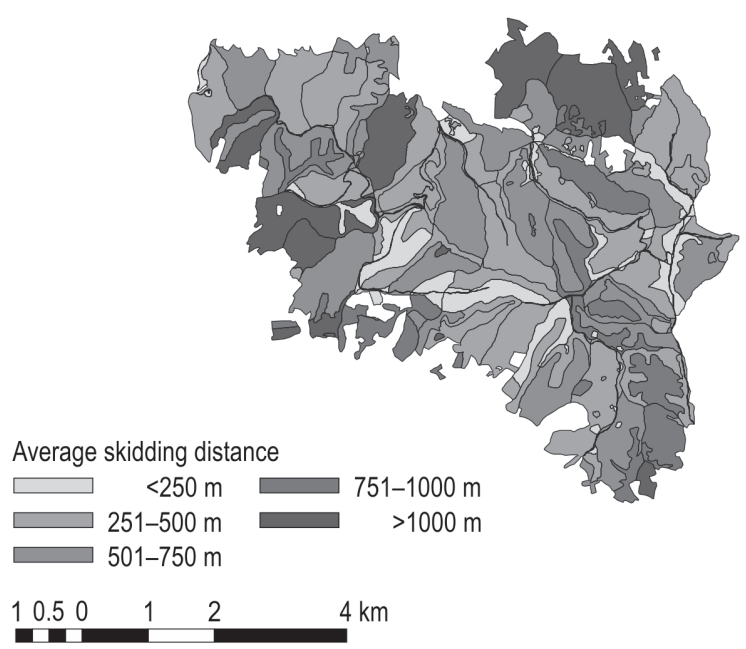

Fig. 14 Yarding distance - FMU »Prosara»

where areas that are preferable for each of the investigated harvesting systems are defined.

The relative share of the area covered by each harvesting system (Fig. 19) shows that in FMU »KozaraMlječanica « the harvesting system chainsaw-skidder has the highest share, $44 \%$ of the area, meaning that this system is currently dominant; it is followed by chainsaw-forwarder (36\%), chainsaw-cable yarder

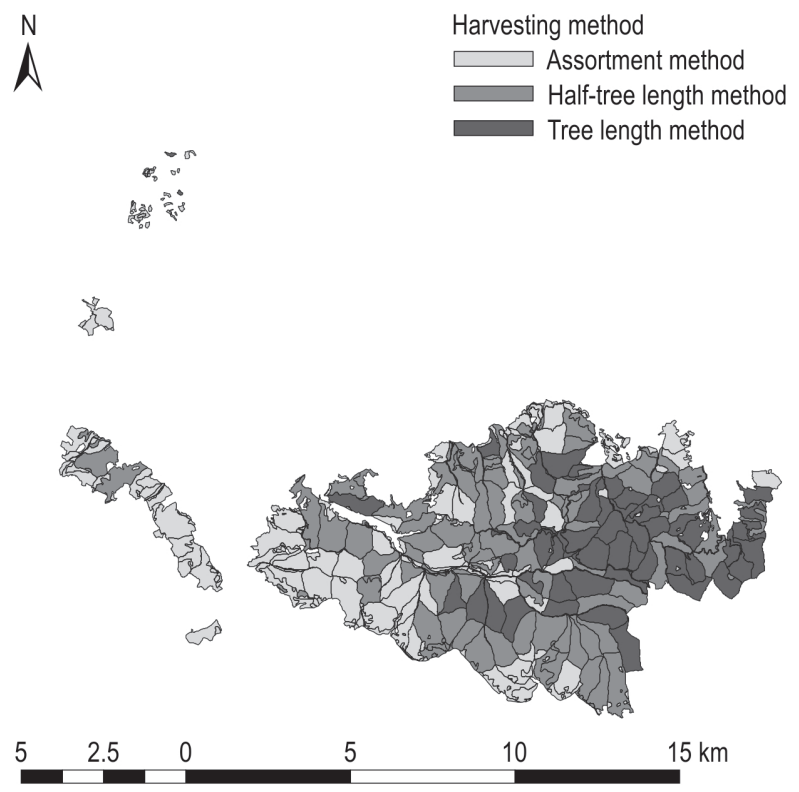

Fig. 15 Harvesting method - FMU »Kozara-Mlječanica»

$\stackrel{N}{\Lambda}$

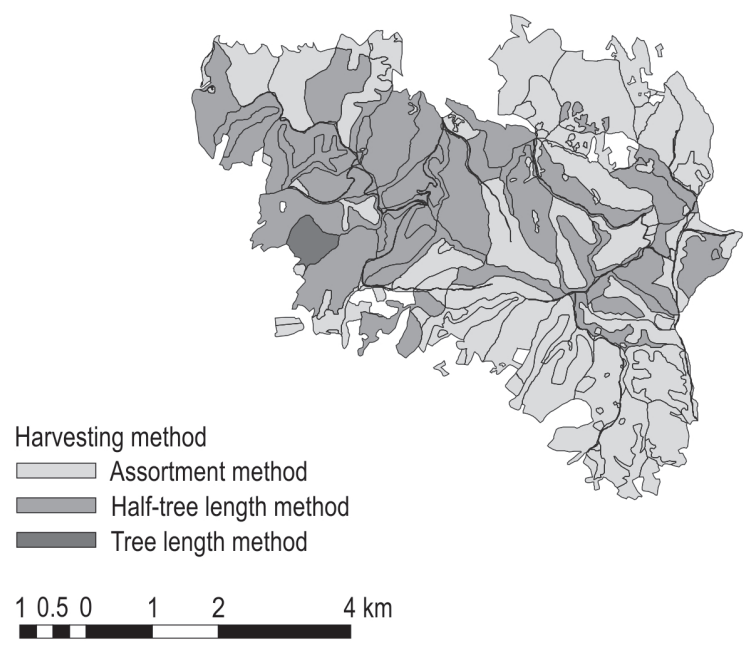

Fig. 16 Harvesting method - FMU »Prosara»

(19\%), and chainsaw-AAT (1\%). The system harvesterforwarder was not used at all, which is understandable considering the fact that the average slope and DBH of cutting tree are higher in FMU »Kozara-Mlječanica« than in FMU »Prosara «, where the harvester-forwarder system accounts for a significant $36 \%$ of the area. The prevalent system in FMU »Prosara « is chainsawforwarder $(42 \%)$, followed by chainsaw-cable yarder 


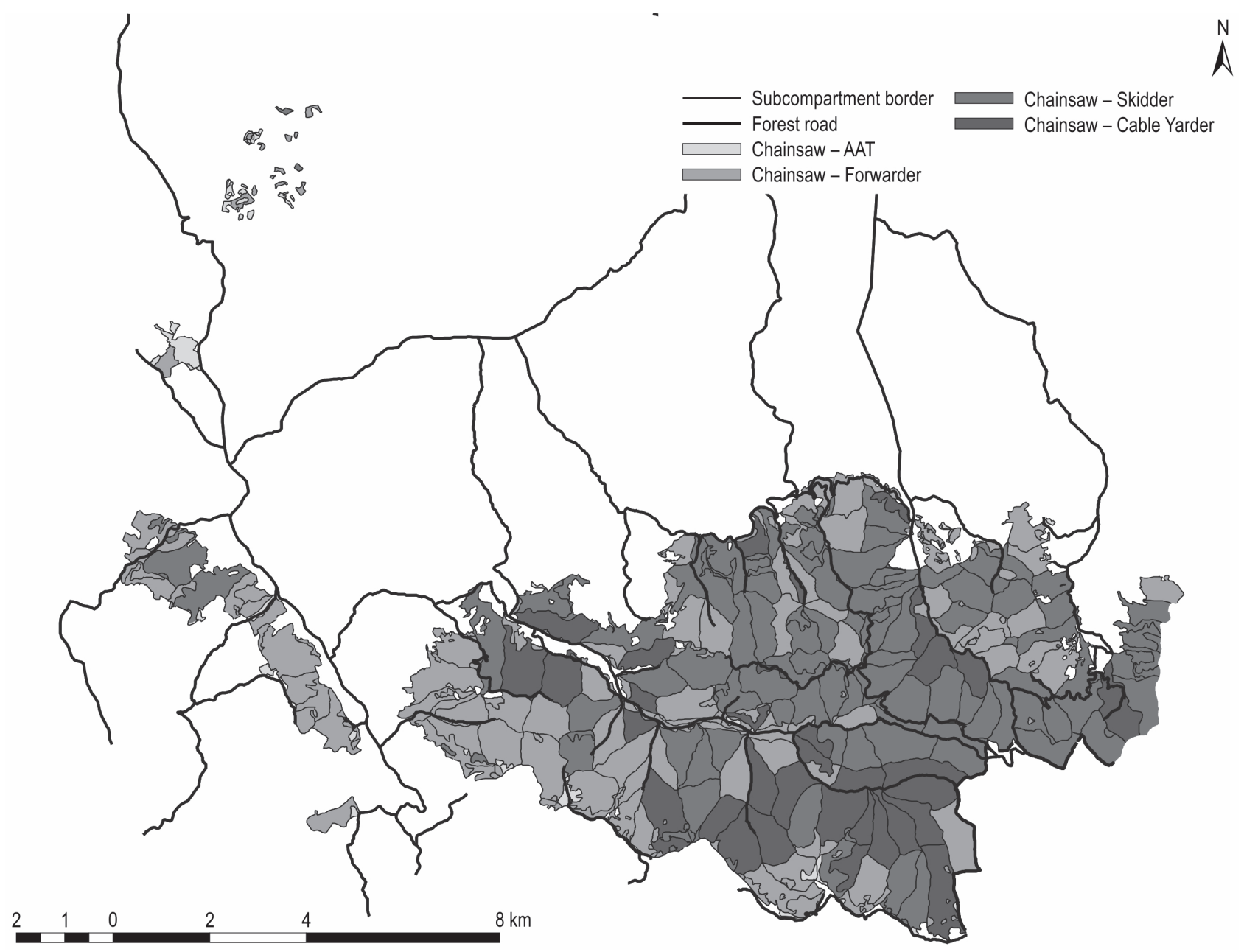

Fig. 17 Harvesting system suitability map - FMU »Kozara-Mlječanica»

(17\%), chainsaw-skidder (4\%) and chainsaw-AAT (1\%). It should be noted that the use of the chainsawskidder system is insignificant. It was replaced by the system chainsaw-forwarder. This result confirms the long-standing discussion among local practitioners that there are very strong reasons for encouraging the introduction of forwarders in local forestry. The results of this study showed that GIS and other supporting tools could save significant amount of time and costs, and open new possibilities in harvesting planning. Çalişkan and Karahalil (2017) reached similar conclusions. Yoshioka and Sakai (2005), who analysed the amount of forest biomass available as an energy resource in mountainous regions, also reached comparable conclusions. This study was based on a GIS analysis including three machinery types (skidder, tower yarder, and sledge yarder) and three biomass resources (logging residues, thinned trees, and broadleaved forests). Adams et al. (2003) analysed different locations according to harvesting system suitability for wheeled and tracked skidder, cable yarder and helicopter for the area of 500 ha of mountainous terrain in south-west Virginia, and concluded that GIS models designed to utilise publicly available spatial data, such as the steep terrain harvesting risk assessment model, free up resources that would otherwise be needed for data acquisition and are accessible to a wide audience of users.

\section{Conclusions}

Planning of harvesting operations in Bosnia and Herzegovina is still done in an »old-fashioned « manner. Practitioners use various inputs that are based on local regulations and rules that origin from investigations that were done a few decades ago. Using of modern tools for planning and introducing new machinery is a necessity, especially if we consider that there has 


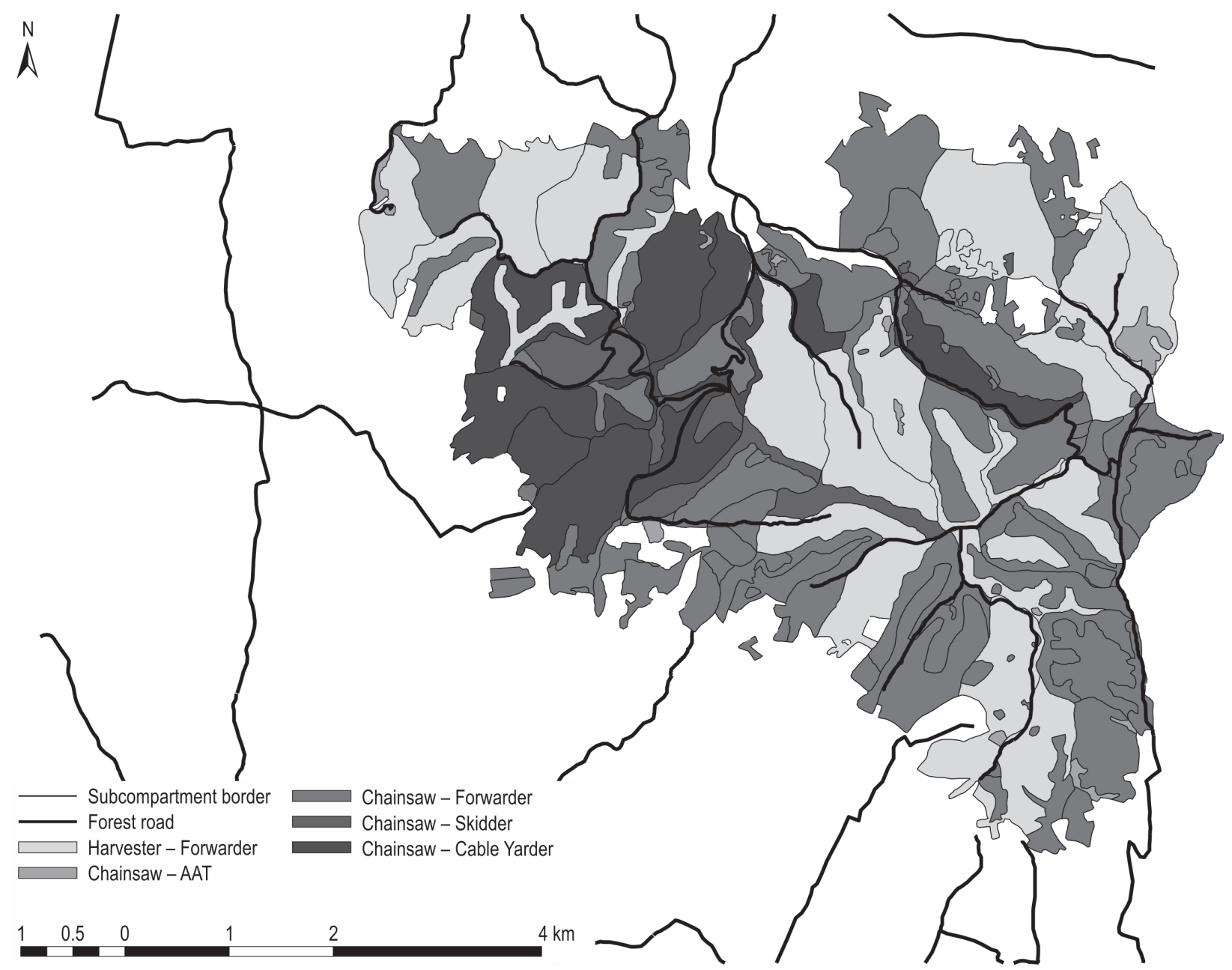

Fig. 18 Harvesting system suitability map - FMU »Prosara»

been a huge lack of human labour in recent years, what is a growing issue for forest managers. Investments in new technologies is a very demanding step for the forestry sector and should be planned very carefully. Using the AHP method, integrated with GIS software, improves and facilitates planning of forest operations and could be used in selection cutting forests with natural regeneration. This investigation showed how opinions of forestry practitioners, available data and contemporary tools could be integrated into the process of planning of harvesting operations in term of choosing optimal harvesting system. Grigolato et al. 2017 concluded that the application of GIS in forest harvesting and transportation engineering as well as in forest operations management would expand in the near future. This case study of two typical FMUs showed that there is a great potential for replacing traditional forestry practice with the contemporary harvesting systems. Diversification of a large harvesting area, ideally of the total country forest area, into

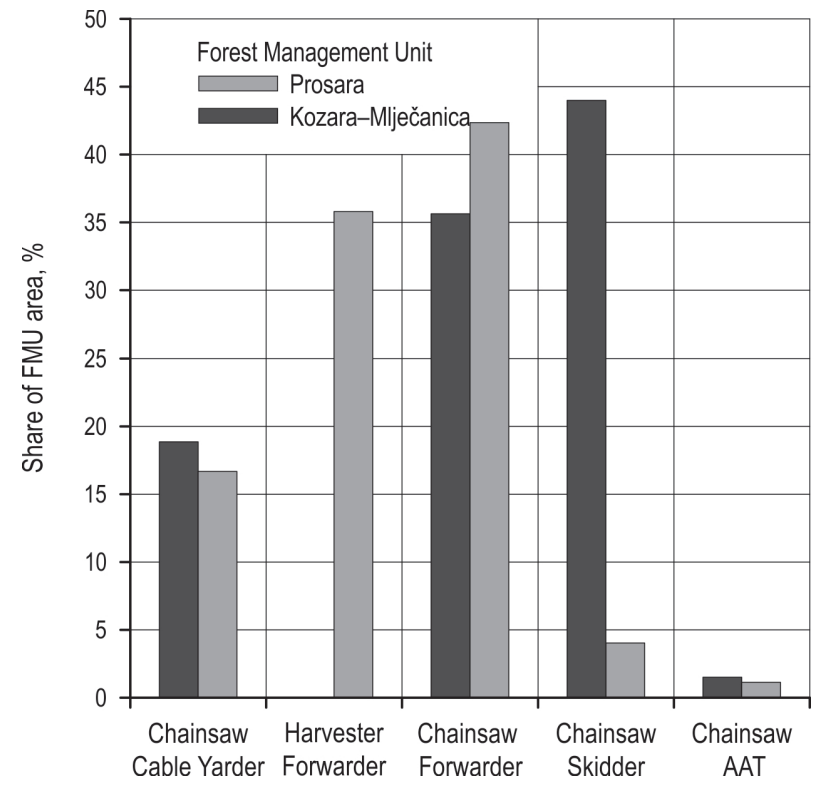

Fig. 19 Relative share of harvesting systems 
harvesting system suitable categories could be of great help for planning of investments in new technologies and embracing new, improved working methods. Of course, this process should be followed by appropriate legislative harmonisation, standardisation, cost analysis and education.

\section{References}

Adams, J.D., Visser, R.J., Prisley, S.P., 2003: Modelling steep terrain harvesting risk using GIS. Proceedings of Austro 2003: High Tech Forest Operations for Mountainous Terrain, October 5-9, Schlaegl, Austria.

Babapour, R., Naghdi, R., Salehi, A., Ghajar, I., 2014: A decision support system for allocation of mountain forest roads based on ground stability. Arabian Journal for Science and Engineering 39(1): 199-205. https://doi:10.1007/s13369-0130833-5

Blagojević, B., Jonsson, R., Björheden, R., Nordström, E.M., Lindroos, O., 2019: Multi-Criteria Decision Analysis (MCDA) in Forest Operations - an Introductional Review. Croatian Journal of Forest Engineering 40(1): 191-2015.

Boyland, M., Nelson, J., Bunnell, F.L., 2004: Creating land allocation zones for forest management: a simulated annealing approach. Canadian Journal of Forest Research 34(8): 1669-1682. https://doi.org/10.1139/x04-048

Çalişkan, E., Karahalil, U., 2017: Evaluation of Forest Road Network and Determining Timber Extraction System Using GIS: A Case Study in Anbardağ Planning Unit. Šumarski list 141(3-4): 163-171. https://doi.org/10.31298/sl.141.3-4.6

Chung, W., Stückelberger, J., Aruga, K., Cundy, T.W., 2008: Forest road network design using a trade-off analysis between skidding and road construction costs. Canadian journal of forest research 38(3): 439-448. https://doi.org/10.1139/ X07-170

Contreras, M.A., Parrott, D.L., Chung, W., 2015: Designing skid-trail networks to reduce skidding cost and soil disturbance for ground-based timber harvesting operations. Forest Science 62(1): 48-58. https://doi.org/10.5849/forsci.14-146

Coulter, E.D., Sessions, J., Wing, M.G., 2006: Scheduling forest road maintenance using the analytic hierarchy process and heuristics. Silva Fennica 40(1): 143. https://doi. org/10.14214/sf.357

Diaz-Balteiro, L., Romero, C., 2008: Making forestry decisions with multiple criteria: A review and an assessment. Forest ecology and management 255(8-9): 3222-3241. https:// doi.org/10.1016/j.foreco.2008.01.038

Đuka, A., Grigolato, S., Papa, I., Pentek, T., Poršinsky, T., 2017: Assessment of timber extraction distance and skid road network in steep karst terrain. iForest 10: 886-894. https:// doi.org/10.3832/ifor2471-010

Đuka, A., Poršinsky, T., Pentek, T., Pandur, Z., Vusić, D., Papa, I., 2018: Mobility Range of a Cable Skidder for Timber
Extraction on Sloped Terrain. Forests 9: 526. https://doi. org/10.3390/f9090526

Epstein, R., Weintraub, A., Sapunar, P., Nieto, E., Sessions, J.B., Sessions, J., Musante, H., 2006: A combinatorial heuristic approach for solving real-size machinery location and road design problems in forestry planning. Operations Research 54(6): 1017-1027. https://doi.org/10.1287/ opre.1060.0331

Ezzati, S., Najafi, A., Yaghini, M., Hashemi, A.A., Bettinger, P., 2015: An optimization model to solve skidding problem in steep slope terrain. Journal of Forest Economics 21(4): 250-268. https://doi.org/10.1016/j.jfe.2015.10.001

Ezzati, S., Najafi, A., Bettinger, P., 2016: Finding feasible harvest zones in mountainous areas using integrated spatial multi-criteria decision analysis. Land Use Policy 59: 478-491. https://doi.org/10.1016/j.landusepol.2016.09.020

Gerasimov, Y., Senko, S., Karjalainen, T., 2013: Prospects of forest road infrastructure development in northwest Russia with proven Nordic solutions: Scandinavian journal of forest research 28(8): 758-774. https://doi.org/10.1080/02827581.20 13.838299

Ghajar, I., Najafi, A., Ezzati, S., 2010: Skidding machines allocation (SMA) using fuzzy set theory. Croatian Journal of Forest Engineering 31(2): 99-110.

Gond, V., Freycon, V., Molino, J.F., Brunaux, O., Ingrassia, F., Joubert, P., Sabatier, D., 2011: Broad-scale spatial pattern of forest landscape types in the Guiana Shield. International Journal of Applied Earth Observation and Geoinformation 13(3): 357-367. https://doi.org/10.1016/j.jag.2011.01.004

Grigolato, S., Mologni, O., Cavalli, R., 2017: GIS applications in forest operations and road network planning: An overview over the last two decades. Croatian Journal of Forest Engineering 38(2): 175-186.

Heinimann, H.R., 2000: Forest operations under mountainous conditions. In Forests in sustainable mountain development: a state of knowledge report for 2000. Edited by M.F. Price and N. Butt. CABI, Wallingford. 224-230.

Heinemann, H.R., 2004: Forest operation under mountainous conditions. In: Burley J., Evans J., Youngquist J. (eds). Encyclopedia of Forest Sciences, Amsterdam: Elsevier Academic Press: 279-285.

Jaafari, A., Najafi, A., Rezaeian, J., Sattarian, A., 2015: Modeling erosion and sediment delivery from unpaved roads in the north mountainous forest of Iran. GEM-International Journal on Geomathematics 6(2): 343-356. https://doi. org/10.1007/s13137-014-0062-4

Kangas, J., Kangas, A., 2005: Multiple criteria decision support in forest management - the approach, methods applied, and experiences gained. Forest ecology and management 207(1-2): 133-143. https://doi.org/10.1007/978-94-015-99061_3

Kangas, A., Kangas, J., Kurttila, M., 2008: Decision support for forest management (Vol. 16). Berlin: Springer. XII: 222 p. 
Kazana, V., Fawcett, R.H., Mutch, W.E., 2003: A decision support modelling framework for multiple use forest management: The Queen Elizabeth Forest case study in Scotland. European Journal of Operational Research 148(1): 102-115. https://doi.org/10.1016/S0377-2217(02)00348-X

Krpan, A., Poršinsky, T., 2004: Efficiency of Mechanical Felling and Processing in Soft and Hardwood broadleaved stands - Part 1: Attitudes of Forest Professionals towards Mechanical Felling and Processing. Šumarski list 128(3-4): 127-136.

Kühmaier, M., Stampfer, K., 2010: Development of a multiattribute spatial decision support system in selecting timber harvesting systems. Croatian Journal of Forest Engineering 31(2): 75-88.

Laengin, D., Ackerman, P., Krieg, B., Immelman, A., Potgieter, C., Van Rooyen, J., Upfold, S., 2010: South African ground based harvesting handbook. Forest Engineering Southern Africa and Institute for Commercial Forestry Research: 1-182.

Lexer, M.J., Vacik, H., Palmetzhofer, D., Oitzinger, G., 2005: A decision support tool to improve forestry extension services for small private landowners in southern Austria. Computers and electronics in agriculture 49(1): 81-102. https://doi.org/10.1016/j.compag.2005.02.004

Lubello, D., 2008: A rule-based SDSS for integrated forest harvesting planning. PhD thesis. Padova: Universita Degli Studi di Padova: 1-217 p.

Lüthy, D., 1998: Entwicklungeines »Spatial decision support« Systems (SDSS) für die Holzernteplanung in steilen Geländeverhältnissen (Development of a SDSS for timberharvesting in steep terrain). Zürich: Vdf, Hochschul-Verl.an der ETH. 260 p.

Malhotra, N., 2007: Marketing research - an applied orientation, Pearson Prentice Hall, Upper Saddle River: 1-811.

Marčeta, D., 2015: Comparison of technologies of wood biomass utilization in beech stands. PHD Thessis, University of Ljubljana, Biotechnical faculty, Ljubljana, Slovenia, 1-157.

Marčeta, D., Petković, V., Košir, B., 2014: Comparison of two skidding methods in beech forests in mountainous conditions. Nova mehanizacija šumarstva 35: 51-62.

Marinoni, O., 2004: Implementation of the analytical hierarchy process with VBA in ArcGIS. Computers \& Geosciences 30(6): 637-646. https://doi.org/10.1016/j.cageo.2004.03.010

Mendoza, G.A., Martins, H., 2006: Multi-criteria decision analysis in natural resource management: a critical review of methods and new modelling paradigms. Forest ecology and management 230(1-3): 1-22. https://doi.org/10.1016/j. foreco.2006.03.023

Norizah, K., MohdHasmadi, I., 2012: Developing priorities and ranking for suitable forest road: Allocation using Analytic Hierarchy Process (AHP) in peninsular Malaysia. Sains Malaysiana 41(10): 1177-1185

Pellegrini, M., Grigolato, S., 2013: Spatial multi-criteria decision process to define maintenance priorities of forest road network: an application in the Italian Alpine region. Croatian Journal of Forest Engineering 34(1): 31-42.
Perez-Rodriguez, F., Rojo-Alboreca, A., 2012: Forestry application of the AHP by use of MPCC software. Forest Systems: 21(3): 418-425. https://doi.org/10.5424/fs/201221302641

Pentek, T., Poršinsky, T., Šušnjar, M., Stankić, I., Nevečerel, H., Šporčić, M., 2008: Environmentally sound harvesting technologies in commercial forests in the area of Northern Velebit - functional terrain classification. Periodicum biologorum 110(2): 127-135.

PFE »Šume Republike Srpske«, 2018: Forest management plan for Forest management area »Kozaračko«, IRPC, Banja Luka, 1-473.

Richards, E.W., Gunn, E.A., 2000: A model and tabu search method to optimize stand harvest and road construction schedules. Forest Science 46(2): 188-203. https://doi. org/10.1093/forestscience/46.2.188

Saaty, T.L., 1977: A scaling method for priorities in hierarchical structures. Journal of mathematical psychology 15(3): 234-281. https://doi.org/10.1016/0022-2496(77)90033-5

Saaty, T.L., 2008: Decision making with the analytic hierarchy process. International journal of services sciences 1(1): 83-98. https://doi.org/10.1504/IJSSci.2008.01759

Sheppard, S.R., Meitner, M., 2005: Using multi-criteria analysis and visualisation for sustainable forest management planning with stakeholder groups. Forest ecology and management 207(1-2): 171-187. https://doi.org/10.1016/j.foreco.2004.10.032

Šipad Irc Oour Silva 1989: Tables of technical standards in the forests exploitation, Sarajevo, $175 \mathrm{p}$.

Stampfer, K., 1999: Influence of terrain condition sand thinning regimes on productivity of a track-based steep slope harvester. In: J. Sessions and W. Chung [Eds.]. Proceedings of the International Mountain Logging and $10^{\text {th }}$ Pacific Northwest Skyline Symp. March 28-April 1, Corvallis, Oregon, 78-87.

Stampfer, K., Steinmüller, T., 2001: A new approach to derive a productivity model for the harvester Valmet 911 Snake. In Proceedings of international mountain logging and $11^{\text {th }}$ Pacific Northwest skyline symposium - a forest engineering odyssey: 254-262.

Stückelberger, J.A., Heinimann, H.R., Chung, W., Ulber, M., 2006: Automatic road-network planning for multiple objectives. In W. Chung \& H.-S. Han (Eds.), Council on forest engineering conference, Coeur d'Alene, ID, USA, 233-248.

Stückelberger, J., Heinimann, H.R., Chung, W., 2007: Improved road network design models with the consideration of various link patterns and road design elements. Canadian journal of forest research 37(11): 2281-2298. https://doi. org/10.1139/X07-036

Synek, M., Klimánek, M., 2014: Proposal of using GIS for multi-criteria evaluation of environmentally friendly use of skidding technologies in forestry. Journal of Forest Science 60(2): 51-60. https://doi.org/10.17221/88/2013-JFS

Troncoso, J., D'Amours, S., Flisberg, P., Rönnqvist, M., Weintraub, A., 2015: A mixed integer programming model to evaluate integrating strategies in the forest value chain-a 
case study in the Chilean forest industry. Canadian Journal of Forest Research 45(7): 937-949. https://doi.org/10.1139/ cjfr-2014-0315

Wolfslehner, B., Vacik, H., 2008: Evaluating sustainable forest management strategies with the analytic network process in a pressure-state-response framework. Journal of environ- mental management 88(1): 1-10. https://doi.org/10.1016/j. jenvman.2007.01.027

Yoshioka, T., Sakai, H., 2005: Amount and availability of forest biomass as an energy resource in a mountainous region in Japan: a GIS-based analysis. Croatian Journal of Forest Engineering 26(2): 59-70.

(C) 2020 by the authors. Submitted for possible open access publication under the terms and conditions of the Creative Commons Attribution (CC BY) license (http://creativecommons.org/licenses/by/4.0/).

Authors' addresses:

Assist. prof. Dane Marčeta, PhD * email: dane.marceta@sf.unibl.org Assist. prof. Vladimir Petković, PhD e-mail: vladimir.petkovic@sfbl.org University of Banja Luka Faculty of Forestry Bulevar Vojvode Stepe Stepanovića 75 78000 Banja Luka BOSNIA AND HERZEGOVINA

Darko Ljubojević, MSc email: darkoljubojevic@gmail.com PFE »Šume Republike Srpske« a.d. Sokolac, FMA »Prijedor«

Vožda Karađorđa 4/2, 79101 Prijedor BOSNIA AND HERZEGOVINA

Prof. Igor Potočnik, PhD

e-mail: igor.potocnik@bf.uni-lj.si

University of Ljubljana

Biotechnical Faculty

Jamnikarjeva 101

1000 Ljubljana

SLOVENIA

* Corresponding author 